\title{
Examining employer proposals for labour law reform: an American perspective
}

\author{
E.J. Dannin*
}

The article examines proposals advanced by employer organisations for labour law reform, which they claim is modelled on, among others, the American system. The article demonstrates that those claims are seriously flawed and are based on an incomplete and inaccurate understanding of the functioning of the American and other systems.

Since the enactment of the Labour Relations Act in 1987, the New Zealand Employers' Federation and the New Zealand Business Roundtable (hereafter generally referred to as the associations) have vigorously advocated further changes. These include abolishing the award system, compulsory unionism, the blanket coverage of awards, and the Labour Court as well as reforming the adversarial structure of industrial law. A major part of their argument is that these features of labour law are unique to New Zealand (Kerr, 1989; Trotter, 1986b, pp.8-9) and that abolishing them will result in "flexible, decentralised bargaining" enhancing, "through productivity, the returns for both investment of labour and investment capital" (NZEF, 1988c; Fergusson, 1989; NZEF, 1989a; NZEF, 1987; NZBR, 1988; see also Birch, 1987).

This article examines these claims of uniqueness, with a particular focus on industrial relations in the United States, a country frequently cited as a model by these associations. Most of the associations' claims are assertions with no attribution or study cited. Often they appear to be holding up Japan and the United States as their models. Such an examination leads to the inescapable conclusion that, despite their presumed ability to ascertain the truth, the associations have done a very poor job of research, for they are mistaken as to the position in those countries.

\section{Voluntary versus compulsory unionism}

The number one item on the associations' agenda is the elimination of what they refer to as compulsory unionism (and which is referred to in the United States as union security). They claim they want to eliminate compulsory unionism (NZEF, 1989b; NZEF, 1988a, p.3; NZBR, 1989, p.6; Hutton, 1987, p.6), out of concern for the worker,

* The author is an American attorney and writer specialising in the field of industrial relations. The author wishes to thank Massey University Library, the New Zealand Business Roundtable, and the Dan Long Library, for providing access to many of the materials on which this article is based and in addition, all those who read the paper for their helpful comments and encouragement. 
out of concern for freedom, pure and simple. ${ }^{1}$ In a more candid explanation, Lindsay Fergusson of the Business Roundtable sees voluntary unionism as part of a programme "aimed at establishing a free and decentralised system of contracting" that would facilitate "individualised forms of contracting which suit workers whose needs vary from the norm." In other words, he hopes that eliminating compulsory unionism would weaken unions. As is the case with most of the associations' proposals, he also contends that New Zealand and Australia are unique in maintaining compulsory unionism among all other OECD countries (Fergusson, 1989, pp.6-7; NZBR, 1987, p.7; NZBR, 1986, p.47; Rowe, 1983, p.29).

The Labour Relations Act, of course, does not make unionism compulsory in the sense that workers are unable to escape union membership. Workers covered by an award must vote for compulsory membership. In the case of an agreement the statute merely makes it permissible for employers and unions to agree to incorporate compulsory unionism clauses. It does not force employers to agree to them. The law also accommodates those workers who do not wish to belong by providing a process for exemption from membership (ss.82, and 83; see generally Kahn-Freund, 1977, p.201). Workers thus are given the legal ability to choose whether to belong to unions or not.

The moral rightness or wrongness of forced union membership, the philosophical questions of how best to analogise union membership, as akin to citizenship or club membership is a byway that we will forgo visiting in this article. The question here is not concern for the rights of workers or economic power, or even whether people should support or oppose compulsory unionism depending on how they feel about unions maintaining or increasing their power in relation to employers (Hanson, et al., 1982, p.9). The question here is whether New Zealand stands virtually alone in making union membership compulsory.

Anyone who has practiced in the field of industrial relations in the United States longer than a day will know that it has the same feature, although it uses the more benign term, union security. In a decade of practice in the field, I do not recall ever having seen a collective bargaining agreement without a union security clause, and I am also aware that this is an issue unions are adamant about in bargaining. Not only do unions want them as a means of eliminating the problem of the free rider, the presence of a bona fide union security clause is also necessary to invoke the protections of the contract bar doctrine, preventing any other election being held in that unit for as much as 3 years.

Moreover, a survey of other countries found that they are common to all developed countries. In 1980 in Britain, 40 percent of union members worked in closed shops, that is, establishments that required union membership before employment (no figures were given for other forms of compulsory unionism there); in 1980 in the United States, 97 percent of collective bargaining agreements had some form of union security, with 74 percent of construction union contracts providing for a de facto closed shop (a form of union security which is outlawed elsewhere in the United States); in 1977 in Canada, 60 percent of manufacturing employees were covered by union shop provisions and another 8.7 percent by closed shop provisions. These arrangements are common in Japan and even in many European countries where they are outlawed. In Belgium, Denmark, Netherlands, and France the functional equivalent of compulsory unionism exists (Cordova and Ozaki, 1980, pp.28-29). Another study found that in the period 1958-1980, 75 percent of the collective bargaining agreements in the United States had either union

1 When told that an employer refused to agree to compulsory membership "on principle," Judge Sims responded that he did not understand what the principle was, that the argument is used by employers every time and yet he had been unable to discover the principle (Walsh, 1983, pp.15-16; cf., Brosnan, et al., 1985, p.10) 
shop or agency clauses and that in 1980,85 percent had some sort of union security clause (Cullen, 1985, p.306).

Furthermore, compulsory payment of union dues even by non-members is accepted practice in countries, such as Canada, the United States, Belgium, the Netherlands, and Switzerland (Cordova and Ozaki, 1980, p.31).2

Perhaps the United States is often pointed to as an example in this area, (Fergusson, 1989, p.6) as a consequence of certain states' "right-to-work" laws, which proscribe many forms of compulsory unionism. They were enacted as a result of pressure from employer groups hoping to weaken unions in those states. Whether they have accomplished this goal is unclear.

Not a lot is clearly known about their effect, separated from pre-existing conditions, demographic, economic, or technical changes, and the like. It is known that wages are lower in those states; however, they were lower prior to the enactment of right-to-work laws. Some studies find that the gap between union and non-union wages is higher in right-to-work states. This is possibly the effect of unions not needing to trade off wages for union security clauses (Moore and Newman, 1985, pp.579-80). Furthermore, there is little evidence that right-to-work laws have any effect on the level of unionisation or of lessening industrial strife. Indeed, in the period 1964-78, there was a 45.6 percent increase in union membership in those states, as opposed to only a 4 percent increase in other states (Hanson et al., 1982, pp.154-56; Delaney et al., 1985, p.62). Part of this disparity can be explained by the effect of a lower base in right-to-work states. Finally, "strikes are more likely to occur and are more severe in states with right-to-work statutes than elsewhere" (Gramm, 1986, p.373).

Developing countries also support union security as a way to improve industrial relations by ensuring industrial stability and social development. Many believe that unions perform important functions in modern society and deserve special protection (Cordova and Ozaki, 1980, p.24), a philosophy akin to that formerly held by New Zealand employers, that compulsory unionism was in their interests by leading to less workforce unrest and militancy (Brosnan, 1983, pp.2-3; Rudman, 1974, pp.61-63; Harbridge and Walsh, 1985, p.202; Hanson et al., 1982, p.13).

Before leaving this issue, it is interesting that in a debate which claims to focus on worker rights, there has not been greater discussion of actual worker behaviour. Objective data are available. For instance, Howells has compiled statistics of ballots by union membership after 1977 on whether to retain an unqualified preference clause. He found no groundswell of worker opposition to compulsory unionism (Howells, 1983, pp.100-101, 106). The exercise was quite expensive. Balloting alone was estimated at $\$ 600,000$, plus time lost to normal activities. The Department of Labour incurred $\$ 500,000$ travel expenses, plus employee salaries supervising the elections. Lost production time was estimated at 14,772 days, exceeding the time lost in the second and third most strike prone industries in 2 of 4 years preceding 1976 (Howells, 1983, p.107; Walsh, 1983, p.20).

Harbridge and Walsh have dealt with the period after 1984, as a consequence of the Industrial Relations Amendment Act, which outlawed compulsory unionism. They found that most unions lost but between 1 and 5 percent of members during that period, with some of those losses actually attributable to redundancies as opposed to refusals to join (Harbridge and Walsh, 1985, pp.199-200)

Under the Labour Relations Act, workers vote on compulsory unionism if employers refuse to agree to a union membership provision. As at 18 October 1989, 44 ballots had been held, approximately 10 to 20 percent of those which are likely to be held. All supported including union membership provisions (Fuller, 1989, p.14). According to the 
Office of the Registrar of Unions, that figure had risen to 70 ballots by February 13, 1990, all supporting compulsory unionism.

Whatever interpretation can be made of worker behaviour, it can at least be said that workers are not seizing opportunities to rid themselves of compulsory unionism. The interpretation of how the associations managed to miss the mark by so much is less clear.

\section{Voluntary representation}

The associations are not only concerned about worker lack of freedom as represented by compulsory unionism. They are also distressed that New Zealand workers are denied freedom of association by being represented by unions they personally may not have selected (NZBR, 1989, p.7; NZBR, 1986, p.48; Fergusson, 1989, p.9). They want a procedure that does away with this. The practical effect of abolishing the current system is unclear. Workers have many views and different desires. Full freedom to choose could lead to many unions representing an employers' workforce, with greater workplace strife and militancy. Competing unions increase demarcation disputes and the need for frequent negotiation (Brosnan, 1983, pp.2-3; Edwards, 1986, p.145)

This could also conflict with the associations' proposals that each worksite have one representative. It cannot be that workers both exercise full freedom of choice and yet are represented only by one enterprise-wide agent.

Returning to the fundamental question addressed here, is New Zealand unique in not permitting workers unfettered freedom to choose? Again, the answer is that New Zealand's system has parallels abroad and not only in Australia. Many countries base their framework for industrial relations on exclusive bargaining rights for a union (Cordova and Ozaki, 1980, p.26). In the United States, section 9(a) of the National Labor Relations Act provides:

\footnotetext{
Representatives designated or selected for the purpose of collective bargaining by the majority of the employees in a unit appropriate for such purposes, shall be the exclusive representative of all the employees in such unit for the purposes of collective bargaining in respect to rates of pay, wages, hours of employment, or other conditions of employment.
}

A union is given this right if it is chosen by more than 50 percent of the unit. As institutions of a democratic country, it is not surprising that New Zealand unions operate by the principle of majority rule. Indeed in the corporate context, shareholders or officers representing a minority view would not be permitted to divide the corporate structure. They are expected to pull behind the majority view.

\section{Award coverage}

Next to compulsory unionism, employer organisations are most opposed to award coverage as opposed to enterprise bargaining (NZEF, 1989a; NZEF, 1988a, p.3; NZBR, 1989, pp.7-9; NZBR, 1987a, pp.5-6), also referred to as decentralised labour relations (NZEF, 1988c; NZBR, 1987, p.5; NZBR, 1986, pp.5, 44). The Business Roundtable claims: "Uniform national agreements are virtually unknown outside" Australia and New Zealand (Trotter, 1986a, p.9). Prior to the enactment of the Labour Relations Act, New Zealand provided for enterprise bargaining through secondary agreements (NZPC, 1986, pp.41-43; Harbridge and McCaw, 1989, pp.150-152; NZBR, 1987b, p.14). Employer organisations contend that the system does not take into account employer ability to pay 
and the possible existence of multiple agreements or awards applying in one workplace (Bradford, 1983; Rose, 1986, p.73).

Again, New Zealand is not unique in the existence of bargaining agreements which, like awards, extend beyond the single workplace. The level at which bargaining takes place in a country depends on factors such as national traditions, the structure of employer and employee organisations, the level at which employee solidarity is felt, the size of the country, tactical considerations, and economic conditions (ILO, 1977, p.28).

The Business Roundtable cites the United States as a successful model of a decentralised bargaining system (NZBR, 1987a, p.10). In the United States, unions are certified as representatives in units based on an employer's organisation in a craft, plant, employer-wide, or subdivision unit. Unions in the United States thus begin their representation at precisely the point desired by New Zealand employer organisations.

This is not where the matter ends. Once a union has representation rights, the National Labor Relations Board (NLRB) is indifferent to the unit in which negotiations thereafter take place. Unions and employers can and do voluntarily alter representational units and, with them, agreement coverage (Weber, 1967, p.23).

What do they choose? By 1961, of 150,000 collective bargaining agreements in the United States, multi-plant agreements dominated the manufacturing sector and multiemployer agreements the non-manufacturing sector (Weber, 1967, p.25). More recently, 12 percent of contracts in production units were on a multi-employer basis and of 2034 single employer contracts, 29 were company-wide and based on industry-wide patterns, ${ }^{3}$ 125 were company-wide, and 49 involved multiple unions and were company-wide (Hendricks and Kahn, 1982, p.198). In the non-manufacturing sector, the trend to multiemployer agreements is much stronger, particularly in transportation and construction industries. In 1980, 33.6 percent of non-manufacturing contracts were multi-employer and 13.9 percent were multi-plant. When manufacturing and non-manufacturing are combined, 40.4 percent are multi-employer (Freeman and Medoff, 1984, p.39; see also Derber, 1984, pp.83-93).

European countries such as West Germany, Sweden, and Italy have also moved to multi-employer bargaining at the national level (Sisson, 1987, pp.13, 31, 90). In Japan, multi-employer bargaining exists in industries such as shipping, steel and metal, railways, printing and textiles (Sisson, 1987, pp.171-72; Levine, 1984, pp.347-53). In Britain, where multi-employer bargaining has declined since the 1960s, the change has been accompanied by a large number of strikes (Sisson, 1987, pp.18-22).

In addition, in many United States industries, particularly in those most important to the economy, pattern and coalition bargaining, national contracts, or master contracts are the rule. Local supplements, similar in some respects to second tier bargaining are also found (Freeman and Medoff, 1984, p.35; Sisson, 1987, pp.171-72). In British companies in the private sector, nearly half bargain at a multi-employer level (Booth, 1989, pp.23132),

3 There are several terms frequently used in the United States to apply to various types of collective bargaining agreements. The term "pattern bargaining" as used in the United States refers to bargaining in which a contract is negotiated with a leader in an industry, with all subsequent contracts with competitors being based on this pattern. This describes bargaining in the automotive industry. "Master contracts" are common in the trucking industry in which all unionised employers in the industry sign an agreement negotiated at the national level. Local supplements may also be signed with individual plants to embody narrowly restricted local conditions. "Most favoured nation" agreements are often negotiated requiring a union which reaches more favourable terms with a later signing competitor to provide the same terms to earlier signatories, effectively maintaining terms of collective bargaining agreements within narrow boundaries. 
It is impossible to grasp the impact of union bargaining if one simply looks at the percentage of unorganised versus organised workers as the Business Roundtable does (NZBR, 1987b, p.6). Many non-union American employers, including large ones such as IBM, model their wages and benefits on union contracts.

The reasons for choosing the level of bargaining are complex. Employers with a vertical structure comprising several plants may prefer a multi-plant agreement since a strike at one plant will mean a stoppage of all production (Weber, 1967, pp.21-22). Small employers may prefer multi-employer bargaining to compensate for a power deficiency, to lower bargaining costs, or to ensure that competitors have made the same deal and will be hit with a strike at the same time, preventing them from increasing their market share (Weber, 1967, pp.15-17, 19; Booth, 1989, p.226; Sisson, 1987, pp.6-7; NZPC, 1986, p.47; Kahn-Freund, 1977, p.132; Department of Labour, 1985, p.22). In times of technological or economic change, multi-employer bargaining can allow more successful resolutions of the ensuing problems (Willman, 1986, p.138).

Not everyone opts for multi-employer bargaining. Unions may prefer to bargain at the lowest level to target one employer, set a pattern agreement while that employer's competitors are still in operation, and then whipsaw later employers (Booth, 1989, p.228; Weber, 1967, pp.20-21). This occurred with second tier bargaining in New Zealand (Pearson and Thorns, 1983, p.22). Such an arrangement also has the advantage to the union that not all members need be on strike at the same time. Unions may also prefer single employer bargaining as being more responsive to that workplace's needs and thus resulting in higher union affiliation among the membership (ILO, 1977, p.30).

Employers who dominate a particular industry generally prefer single employer bargaining, feeling they can negotiate the agreement best for them, including one that involves a higher settlement than their competitors can manage in the hope that they will be forced to follow the pattern and then be put out of business (Booth, 1989, p.227; but cf., NZBR, 1989, pp.11-12). Some have suggested that enterprise or decentralised bargaining results in a higher level of disarray in the workplace and increased work stoppages (Barkin, 1981, p.13; Hince, 1986, p.17).

It is curious that employer organisations have taken such a strong stand on this issue, since their membership includes employers of all sizes, in all sorts of industries, with a multiplicity of needs. This was noted by the Department of Labour at the time submissions were made on the Labour Relations Act 1987 (Department of Labour, 1986, p.v).

In any case, the Labour Relations Act allows an employer to negotiate at the enterprise level by inducing the union to do so, although the New Zealand Business Roundtable doubts their ability to do this (NZBR, 1987, p.15). They can bargain less frequently by seeking agreements or awards for longer terms. These would have the advantage of making conditions more certain for a longer period but the disadvantage of providing less flexibility to meet changing conditions.

Nothing in the current legislation prohibits employers from offering combinations of inducements and persuasion to achieve the form of bargaining they desire. To the extent they have not been successful, is not because of the Labour Relations Act but because others have not been persuaded.

\section{Single union bargaining}

Employer associations have advocated having all employees of one employer represented by a single union (NZBR, 1987a, p.5; NZBR, 1986, p.45; NZEF, 1987, pp.4-5). Currently, a New Zealand employer may have to deal with more than one union in the workplace. Again, New Zealand is not alone in this. In the United States, for example, it is not unusual for an employer to bargain with more than one union. 
Hospitals present the most telling example. Congress mandated that there be no proliferation of bargaining units within health care institutions. After years of court battles and agency hearings, rules were promulgated finding 8 units to be presumed appropriate in the hospital context. ${ }^{4}$ No other industry has a requirement of nonproliferation.

Multiple bargaining units and agents do not favour one side or the other. It has been the experience of the NLRB that employees are best represented within a unit of employees performing like work under similar conditions as opposed to being amalgamated in group with diverse interests, represented by a labour organisation not familiar with their terms and conditions of employment. Having more than one unit of representation may have an advantage to an employer of being able to continue operations in the event of a strike.

The infatuation of the associations with enterprise unions might best be explained by the following passage from one of their submissions:

\begin{abstract}
Why do Japanese unions allow a degree of flexibility that would be an anathema to American unions? The reason: they are organised company-wide rather than industry-wide. Because national unions in Japan rarely control locals' policies, a single industry contains several different 'enterprise unions' as they are called, and these unions compete with one another. Workers will moderate wage demands rather than jeopardise their firm's market share (NZBR, 1987b, pp.9$10)$.
\end{abstract}

\title{
5. Labour courts
}

Employer associations regularly argue for the abolition of the Labour Court's jurisdiction. They prefer that their jurisdiction be placed in the regular civil courts (NZBR, 1986, pp.iii, iv, 5-6, 11, 32, 40, 47).

The Labour Court has virtually exclusive jurisdiction over industrial disputes (Labour Relations Act, sections 278-308). While the Court normally consists of a judge alone, it has a tripartite structure of a legally trained judge assisted by two panel members nominated by organisations of employers and unions to deal with personal grievances and demarcation disputes (Labour Relations Act s.286; see also Department of Labour, 1986, pp.18-19; Vranken and Hince, 1988). Such a structure is common to European countries and the rest of the world (Aaron, 1985, pp.36-37; Vranken and Hince, 1988, pp.121-22). The United States, differs in not having such a structure in its government labour courts but does retain it in certain arbitration situations.

The United States does maintain government agencies, including one of cabinet level, to investigate, prosecute, and decide violations of labour law: primarily the NLRB and the Department of Labor. The NLRB performs certain adjudicatory functions similar to the Labour Court but, in addition, prosecutes defined violations, such as illegally discriminatory acts and bargaining in bad faith. Furthermore, in its 50 years of existence it has developed a body of law specific to the regulatory needs of the workplace. These reflect an understanding that industrial law must develop without importing inappropriate common law concepts:

4 See St. Francis Hospital, 271 NLRB No.160 (1984) and its progeny and resulting regulations, which find 8 units (doctors, nurses, other professionals, technicals, skilled maintenance, business office clericals, guards, and other non-professionals) to be presumptively appropriate in the hospital setting, setting the matter at rest. See Monthly labor review. 112(8): 52 . 
Industrial law, or labour law, is clearly distinct from other related areas of study such as commercial or company law because of its social dimension. It is concerned with labour or work which is done in a position of (legal) subordination... It is only because the principles of freedom to contract are of little use in what is essentially a relationship of economic dependence between "master" and "servant" that workers become organised... It must be borne in mind, though, that an acknowledgement of the weak bargaining position of the individual worker is what industrial law is all about (Vranken, 1986, p.5).

Industrial law developed because the common law was inadequate to deal satisfactorily with common events in the workplace, such as discharge or dissatisfaction with wages or other working conditions (Wilson, 1979, p.1; Atleson, 1983, pp.13-14, 94). Dependence upon common law contract concepts, for example, necessitates fitting the industrial reality to a Procrustean bed based on mutuality and freedom of contract, all the while requiring that one party to the relationship remain subservient to the daily and even changing demands of the other (Smith, 1975, pp.341-343, 365).

To create law specifically applicable to the industrial context and then leave its interpretation and application in the hands of civil judges imbued with the common law will inevitably lead to an admixture of concepts which the law was enacted to be rid of (Wedderburn, 1987, pp.13-17; Kahn-Freund, 1977, pp.12-14, 162). The Labour Court judges have articulated the need to ensure that New Zealand's industrial law is applied in a manner consistent with reality and the purpose of the legislation. At his swearing in, Judge Goddard stated:

I am conscious of the task that confronts me. The Labour Court plays a unique role in promoting and advancing harmony in the workplace. Harmony leads to productivity and productivity leads to more jobs, but it does more than that. It also conduces to that caring, tolerant and just society for which we all long....This Court uses special techniques of dispute resolution. Most of its cases are decided not according to rigid or inflexible absolute rules of law but according to equity and good conscience. What this means is not generally understood. Equity is fair play in action. Equity and good conscience involves an ethical approach to the Court's work on a case by case basis. It involves the Court in a persuasive as much as a coercive role and in a protective one in suggesting improved standards of conduct in the workplace, leading to that high level of mutual trust and confidence between employers and workers and between workers and their fellows necessary for the effective functioning of industry (Anon., 1989, p.30).

The common law system has been largely irrelevant to New Zealand collective labour law since 1894, when New Zealand opted for a statutory system (Anderson, 1987, pp.9192). The common law system based itself on the primacy of private property and employer prerogative (Wedderburn, 1987, pp.13-14). Atleson observes that the common law courts have essentially implied into the formation of the employment contract a presumption that the employer has the right to seek to create the largest possible gap between the yield of its assets (i.e. workers) and the cost of hire. (Atleson, 1983, p.14.). A return to the common law could be at the expense of developing a body of law relevant to industrial life.

\section{6 . Continued representation}

Employer associations also are ambitious to curtail the continued representational status of unions. One way they propose to do this is by permitting employers to offer individual contracts to workers, in essence, bidding against their union (NZEF, 1987, p.3; NZBR, 1986, pp.iv, 6-7, 47). The Business Roundtable claims that such "development 
of non-unionised arrangements" is permitted elsewhere, but without specifying where (NZBR, 1986, p.49).

Such a system could create chaos in the workplace, undercutting attempts to resolve workplace problems. At the time of expiration there could be weeks and months of uncertainty as an employer waged negotiations on several fronts. Bitterness and uncertainty, the seeds of industrial unrest, would find fertile ground.

Putting aside questions of the wisdom of fomenting chaos in the workplace, is such a practice permitted in the United States? The answer is that such an action in the United States would violate at least 3 sections of the NLRA. United States employers are prohibited from dealing directly with employees or offering to those who cross the picket line higher wages than have been offered across the bargaining table. ${ }^{5}$ Such an offer is evidence per se of bargaining in bad faith, a violation of section 8(a)(5) of the NLRA. The failure to have such a requirement may be the weakest link in the New Zealand system of labour law at present. It permits and even encourages the employer to draw out negotiations hoping the union will be pressured to settle cheaply as its award nears its death, thereby essentially rewarding those who do not live up to their social obligation to engage in collective negotiations.Depending on the scale of the violation, section 8(a)(2) of the NLRA would also likely be violated, and either scheme would violate section $8(\mathrm{a})(1)$.

The next time the associations venture into this sort of claim as to other countries' systems, it might want to add the congressional hearings for the Wagner Act. The 2 large volumes are replete with speeches inveighing against precisely this sort of behaviour.

\section{The question of the commonality of employer and worker interests}

The associations are particularly up in arms over suggestions that the interests of employers and workers are not one. With righteous indignation, they condemn those benighted souls who seek to put asunder those whom the individual employment contract has joined together. The associations blame adversarial relations on union officials who foster hostility for their own self interest:

The current system... fosters conflict - the myth of an enduring struggle between
capital and labour - where the reality is that employers and workers have a
shared interest in serving consumers, an interest that can only be fostered by
cooperation. It protects the narrow interest of the officials of established
unions at the expense of workers... (Myers, 1989, p.3).

In the battle against adversarial relations, the associations' leitmotif is heard once more: countries such as the United States have abandoned such philosophies (NZBR, 1989, p.14; NZBR, 1987a, p.5; NZBR, undated, p.2; Hutton, 1987, p.4; Freeman and Medoff, 1984, pp.221-39; see also NZBR, 1987b, pp.ii, 4, 6; NZBR, 1986, p.15). The short answer is that there has been no such legislative change in the United States. Some employers and unions have entered into cooperation agreements, just as those in New Zealand can and do under the reviled Labour Relations Act.

This raises an important issue which is implicit in the vision promulgated by the associations. The fundamental statements of the associations which propose a totalitarian view of labour relations, question the value of democratic institutions. It is quite clear that the associations think that it is the role of management to manage, and of labour, recognising the wisdom of management, to acquiesce supinely. Early industrialists 
operated this way (Deeks, 1976, p.27; Atleson, 1983, pp.44-45). Atleson concludes that the fact so many Americans historically were either bound workers, apprentices, or slaves, not free to leave or change their circumstances, has continued to affect the view most Americans hold of the employment relationship and the roles of employer and employee (Atleson, 1983, p.88). and a recent study suggests that these tendencies still exist among New Zealand employers (McAndrew, 1989, pp.142-43). The associations' statements lend further support to that conclusion.

Democracy requires diversity and robust discussion. Blind obedience is not the lot of citizens. How the interests of democracy and those of the corporation are best served is a matter that is at least still open to discussion. This warrants caution and the maintenance of a responsive system, not the straitjacket that has been proposed. The Labour Relations Act already permits setting up the cooperative programmes the associations espouse if they can make a persuasive case to the unions. If unions are not persuaded, the legislative system has not failed. It simply means that the case has not yet been made. Employers are free to marshall their arguments and try again.

The associations may be convinced that differences between employees and employers no longer exist. However, there are people who sincerely believe that important divisions remain and that not until these differences have been composed can it be said there is no need for a legislative system that recognises them.

Those who believe that differences still exist can point to a number of factors as evidence. Employers, for example, want to keep wages low to increase shareholder profits and provide for investment. Workers want real wages set at a living rate or higher. Workers owe respect and deference to their employers both in speech and non-verbal behaviour, but the reverse is not true. Employers want a qualified worker for each job. Workers want to ensure there is a job for each worker. Employers want flexibility to shed excess labour when needed, and as expeditiously as possible, through changes in hours worked, sovereign decision-making as to deployment of workers and job content, and subcontracting. Workers want job security. Employers are supposed to be sober and responsible in their conduct, while employees are assumed to need external controls placed on their behaviour. Employers have control of the workplace and the sole right to regulate worker effort, while employees are controlled and constrained not to regulate their level of effort. Employers see work as outputs of production at a certain level of quality. Workers define work as inputs of effort, time and thought. Finally, and most telling, the evidence is that the employers like their jobs, whereas most workers do not, nor do they find them challenging or fulfilling (Atkinson, 1987, pp.89-91; Atleson, 1983, pp.7-9; NZPC, 1986, pp.5, 21; Kahn-Freund, 1977, p.48; Macarov, 1982, pp.14, 95-96, 100 101).

It is these differences which cause workers to feel a need for effective unions to present their distinct views to management (McDonald, 1974, pp.221, 227). While there need not be all-out war as a result of the different interests of workers and employers, failure to recognise their existence and importance is a failure to deal with reality.

Chief executives prefer to explain industrial conflict as poor communication (Edwards, 1986, p.20), concentrating on conflict in terms of work stoppages alone (Brooks, 1974, p.205). Employer associations have turned to employee involvement schemes to increase productivity and to decrease strike activity. However, when these programmes have been used as a technique to increase production and not to incorporate true participation (Smith, 1978, pp.71, 79), they often decline (Elliger and Nissen, 1987, pp.201-02).

The problem is that an employer cannot express respect for his or her workers, yet claim their views, particularly in choosing union representation, are not legitimate (Smith, 1978, p.74; McDonald, 1974, p.227). Stifling union input as a conduit for worker views may have disastrous effects. These include absenteeism, labour turnover, tardiness, accidents, poor performance, high wastage, lack of care of equipment, demoralisation, working to rule, and even sabotage. This lost productivity can be more costly than strikes, although more difficult to measure (Brooks, 1974, p.205; Brown, 
1977, pp.380-81; Edwards, 1986, pp.10, 37, 50, 73, 249, 256; Willman, 1986, p.202; Deeks, 1976, p.31; Howells, 1974, p.175; Schmidt, 1972, pp.26-28; Atleson, 1983, pp.36-39; Wilson, 1979, pp.3-4). ${ }^{6}$ Grievance systems set up without union involvement have been found insufficient to replace those provided by unions, because employees fear reprisals or feel they are ineffective since a high percentage of decisions uphold management's original decision (Freeman and Medoff, 1984, pp.108-09).

The most strongly expressed complaint by the associations is that unions block change. It has been found that unions do not block legitimate change when they are provided information, equity and access to decision-making but do when the employment relationship is characterised by suspicion (Willman, 1986, pp.106-07; see also Freeman and Medoff, 1984, pp.174-75). It is easy to be frustrated if a union does not feel the same enthusiasm for a change management might like to make (Department of Labour, 1986, pp.1-2) or to be frustrated at not being able to take unilateral action (Freeman and Medoff, 1984 , p.73). However, studies have concluded that management is more often responsible for inefficient labour utilisation. A 1976 British survey of the causes of inefficient labour use found that of the 26 studies surveyed, 21 identified management failures as a cause, and 10 identified them as the key cause. 9 identified unsatisfactory employer-union negotiating procedures as a cause. In contrast, 14 identified union restrictive practices and none found it to be a key cause. Willman also concluded that British managers created unnecessary anxiety among workers facing technological change and displacement, which in turn led to less efficient and satisfactory resolutions (Willman, 1986, p.55-59). In addition unilateral action is unwise since it increases resistance by leaving unions unable to respond on any other level than protecting job security and worker earnings (Willman, 1986, p.166).

Some countries have found that unions contribute to business success. In the United States, the effectiveness of employee involvement programmes in improving quality and productivity, as judged by management, is increased by the percentage of the workforce which is unionised (Cooke, 1989, p.313). Recent studies in the United States have found that a unionised workforce increases productivity by 1 to 2 percent. This is attributed to a lower quit rate caused by the grievance system and features such as seniority which increase employees' security and feeling of having a voice (Freeman and Medoff, 1984, pp.95-109; Freeman, 1980, pp.30, 31), and also to a change in management attitudes resulting in greater cooperation in matters such as introducing new technology (Freeman and Medoff, 1984, pp.174-75). Such an effect was anticipated by the 1894 Industrial Conciliation \&Arbitration Act (Pearson and Thorns, 1983, pp.138-39). This level of improved productivity is, however highly sensitive to the state of labour-management relations (Freeman and Medoff, 1984, p.176).

In addition to improving worker attitudes, collective bargaining causes management to think through contemplated changes, and to explore alternatives in order to present a clear case for the union. In some cases, management may not know the best way to achieve efficiency and, even if it did could not always achieve its goals (Edwards, 1986, pp.22021; Willman, 1986, p.45)7. Added deliberation may save management from dashing to

6 One worker, reflecting on his frustration in working a low paid, wet, difficult job without readily available protective equipment stated: "In fact, most people here like it best when things don't work right and production goes to hell, and I'm right along with them. And that's a crummy way to waste your working time"(Turner, 1987, pp.7-8).

7 In one case studied a chief executive officer sabotaged his employee involvement programme by his unwillingness to change the corporate culture of a unilateral management (Chelte et al., 1989, p.153). The nature of the opposition to unions in New Zealand takes on a different character and is acted upon in different ways than is the case in the United States. In the United States, the battle lines are drawn outside the legislative 
implement every newly attractive trend. They may gain a more sophisticated understanding of the ramifications of the contemplated change. A study of negotiators' attitudes found that after negotiating, the bargainers' appreciation for the validity of the goals of the other side increased (Smith and Turkington, 1981, p.11).

\section{Conclusions}

This analysis is a curious exercise. Anyone who has reached this point should be well aware that basic arguments of the New Zealand Business Roundtable and Employers Federation are objectively untrue. By this I mean that the incorrect assertions made by them cannot be explained by differences in ideology or viewpoint. They ignore well known laws which they could read by opening the appropriate statute book. They ignore clauses found nearly universally in collective bargaining agreements. They ignore phenomena of industrial relations systems commonly discussed and found in books and journals in New Zealand. Finally, they ignore the impact of worldwide economic problems, New Zealand's special problems of size and location, and New Zealand's relatively good performance compared with other countries of its size (Rose, 1986, p.67) and prefer arguments which, even if true, are at best a poor means of explaining New Zealand's economic problems.

Their underlying argument is that unions are illegitimate. They claim this in part because they owe their existence in New Zealand to statute (NZBR, 1986, p.7; see also Wedderburn, 1984, pp.78-79). If owing ones' existence to statute made one illegitimate, then what would be the fate of many members of employer organisations? After all, corporations are not found in nature. They were created by legislative action and would otherwise not be legal. A corporation is nothing but an aggregation of capital given the legal status of a person and permitted to do business while not making those who benefit responsible for its actions (Anderson, 1987, p.94-95; Wedderburn, 1987, p.21; Ireland, et al., 1987, p.149-50, 153).

Indeed, but for the protections in law provided to corporations, unions might be unnecessary (Vranken, 1986, p.7). Unions came into existence to permit workers to deal effectively with the aggregations of capital permitted by the corporate form (Barkin, 1981, pp.2-3). Were corporations to be weighed in the same scale advocated for unions, the current news of employer fraud and mismanagement which has wrought economic havoc and tarnished New Zealand's reputation, might well support a call for an end to the special privileges the corporate form provides. The point, however, is not to fix blame but to gain the sophisticated perspective necessary to make wise decisions.

Perhaps what the employer associations are trying to say is that the balance of power has tilted too strongly towards labour. That is a fair matter for debate and discussion. So far, available objective data do not support that conclusion. For example, a study of the $1987 / 1988$ wage round led to the conclusion that employers had experienced greater power in it and were able to achieve outcomes favourable to them in terms of work rules and

arena. Freeman and Medoff state that despite public awareness of criminality within union ranks, the rate of corporate criminal violations far exceeds that of unions. They speculate that this is caused by the access to large amounts of money by companies and their greater potential to engage in criminal acts (Freeman and Medoff, 1984, pp.214-15). The qualification is necessary since in instances in which labour-management relations deteriorate, productivity suffers. They concluded that in the United States unions have no effect on the profits of competitive firms. They do lower the profit margins of semimonopolistic firms to normal competitive levels (Freeman and Medoff, 1984, pp.18282). In this way, unions serve as a substitute for anti-trust measures, permitting the public to share in those profits (Ulman, 1967, p.1). 
other aspects of awards without having to concede any extra wages (Harbridge and McCaw, 1989, p.161; Harbridge and Dreaver, 1989, p.253-55).

Caution must be exercised in permitting further aggrandisement of power. It goes without saying that if every employer is able to pay its employees as little as possible, soon there will be no workers able to purchase what is produced. (Brosnan and Wilkinson, 1989 , p.52; Abbott, 1989, p.284). Of greater long term danger is economic research that indicates companies paying lower wages have less incentive to become more productive (Brosnan and Wilkinson, 1989, p.16; Willman, 1986, p.45). In the United States, those companies that are unionised and with higher wages can also be the most productive (Freeman and Medoff, 1984, pp.167-70). It may also be that increased worker productivity is most effectively achieved through higher pay rather than tinkering with legislative systems (Macarov, 1982, pp.167-68).

Before considering further changes we must ask, first, whether the fundamental changes advocated may be inimical to a society which has evolved in response to a certain legislative scheme and, second, whether it is wise to tilt the balance of industrial relations even further towards employers. In short, New Zealand will be best served by a labour relations policy that embodies democratic values of justice and tolerance and that is cast in the mould of its unique qualities and national vision.

What is unacceptable, however, is that a powerful segment of a society abdicate its responsibility to the public by pursuing a course to achieve its own ends. Perhaps in the age in which we live, a call for responsibility is so idealistic that the reader will be forced to blush that anyone could be so ingenuous. Risking that, I think it is patently obvious that we need a functioning democracy in order to retain a vibrant, diverse community. Those unwilling to join honestly and seriously in discourse on those terms ultimately do a grave disservice to the spirit of democracy and candid purposeful debate. Without a doubt, the people of New Zealand expect and certainly deserve better.

\section{References}

Aaron, B. (1985) The NLRB, Labor courts, and industrial tribunals: a selective comparison. Industrial and labor relations review. 39(1): 35-45.

Abbott, A. (1989) The new occupational structure: what are the questions? Work and occupations. 16(3): 273 .

Anonymous (1989a) Industrial law bulletin. June 3.

Anderson, G. (1987) The reception of the economic torts into New Zealand labour law: a preliminary discussion. New Zealand journal of industrial relations. 12(2): 89-100.

Atkinson, J. (1987) Flexibility or fragmentation? The United Kingdom labour market in the eighties. Labour and society. 12(1): 87-105.

Atleson, J. (1983) Values and assumptions in American labor law. Amherst, University of Massachusetts Press.

Barkin, S. (1981) Diversity and common challenges on the western collective bargaining scene. Industrial Relations Centre, Victoria University of Wellington.

Birch, B. (1987) The Hon. Bill Birch, National's spokesman on Labour and Employment, outlines the Opposition's Thoughts and Policies on Industrial Relations in New Zealand. The Employer. June 5. 
Booth, A (1989) The bargaining structure of British establishments. British journal of industrial relations. 27(2): 225-234.

Bradford, M. (1983) Issues of concern to employers. In Harbridge, R. (ed) Industrial relations: issues of concern. Industrial Relations Centre, Victoria University of Wellington.

Brooks, B. (1974) Some reflections on industrial conflict in New Zealand. In Howells, J. et al. (eds).

Brosnan, P. (ed) (1983) Voluntary unionism. Industrial Relations Centre, Victoria University of Wellington.

Brosnan, P. (1983) Introduction. In Brosnan, P. (ed).

Brosnan, P., Walsh, P., and Rowe, P., (1985) Democracy and decision making in unions of employers. New Zealand journal of business. 7(1): 1-12.

Brosnan, P. and Wilkinson, F. (1989) Low pay and the minimum wage. Wellington, New Zealand Institute of Industrial Relations Research.

Brown, G. (1977) Sabotage: a study in industrial conflict. Spokesman.

Chelte, A., et al. (1989) Corporate culture as an impediment to employee involvement. Work and occupations. 16(2): 153-164.

Cooke, W. (1989) Improving productivity and quality through collaboration. Industrial relations. 28(2): 299-319.

Cordova, E. and Ozaki, M. (1980) Union security arrangements: an international overview. International labour review. 119(1): 19-38.

Cullen, D. (1985) Recent trends in collective bargaining in the United States. International labour review. 124(3): 299-322.

Dannin, E. (1990) The impact of labour-management cooperation schemes on New Zealand unions. Victoria University of Wellington law review. 20: (forthcoming).

Davis, W. (1989) Major collective bargaining settlements in private industry in 1988. Monthly labor review. 112(5): 34-43.

Davis, W. and Sleemi, F. (1989) Collective bargaining in 1989: negotiators will face diverse issues. Monthly labor review. 112(1): 10-24.

Deeks, J. (1976) Ideology and industrial relations in New Zealand. New Zealand journal of industrial relations. 1(2): 26-31.

Deeks, J. and Boxall, P. (1989) Labour relations in New Zealand. Auckland, Longman Paul.

Delaney, J., Lewin, D., and Sockell, D. (1985) The NLRA at fifty: a research appraisal and agenda. Industrial and labor relations review. 39(1): 361-376. 
Department of Labour (1985) Industrial relations: a framework for review, Volume I. Wellington, Government Printer.

Derber, M. (1984) Employer associations in the United States. In Windmuller, J. and Gladstone, A.

Edwards, P. (1986) Conflict at work: a materialist analysis of workplace relations. Oxford, Basil Blackwell.

Elliger, C. and Nissen, B. (1987) A case study of a failed QWL programme: implications for labor education. Labor studies journal. 11(3): 201.

Fergusson, L. (1989) Labour relations: the state of the debate. Speech to the Institute for International Research Conference: managing change in industrial relations, Auckland.

Freeman, R. (1980) The effect of unionism on worker attachment to firms. Journal of labor research. 1(1): 29-61.

Freeman, R. and Medoff, J. (1984) What do unions do? Basic Books.

Fuller, C. (1989) Evaluating the Labour Relations Act 1987 - unions. In Harbridge, R. (ed).

Geare, A. (1989) Managerial views on compulsory unionism in New Zealand. New Zealand journal of industrial relations. 14(3): 231-240.

Gramm, C. (1986) The determinants of strike incidence and severity: a micro-level study Industrial and labor relations review. 39(3): 361-376.

Hanson, C., Jackson, S. and Miller, D. (1982) The closed shop. Aldershot, Gower.

Harbridge, R. (ed) (1989) Evaluating the Labour Relations Act 1987. Industrial Relations Centre, Victoria University of Wellington.

Harbridge, R. and Dreaver, M. (1989) Changing patterns of working time arrangements in registered agreements in New Zealand. New Zealand journal of industrial relations. 14(3): 251-266.

Harbridge, R. and McCaw, S. (1989) The first round under the Labour Relations Act 1987: changing relative power. New Zealand journal of industrial relations. 14(2): 149167.

Harbridge, R. and Walsh, P. (1985) Legislation prohibiting the closed shop in New Zealand: its introduction and consequences. Journal of industrial relations. 27(2): 191206.

Hendricks, W. and Kahn, L. (1982) The determinants of bargaining structure in United States manufacturing industries. Industrial and labor relations review. 35(2): 181-195.

Hince, K. (1986) The management of industrial relations. New Zealand journal of industrial relations. 11(1): 11-20. 
Howells, J. (1974) Industrial conflict in New Zealand - the last twenty years. In Howells, J. et al. (ed).

Howells, J. (1983) For or against compulsory unionism? Recent ballots in New Zealand. International labour review. 122(1): 95-110.

Howells, J., (ed) (1974) Labour and industrial relations in New Zealand. Carlton, Pitman.

Hutton, A. (1987) Labour market reform and the Labour Relations Act. In New Zealand Business Roundtable (1988).

International Labor Organization, (1977) Collective bargaining in industrialised countries: recent trends and problems. Geneva, International Labour Organisation.

Ireland, P., Grigg-Spall, I., and Kelly, D. (1987) The conceptual foundations of modern company law. Journal of law and society. 14(1): 149-165.

Kahn-Freund, O. (1977) Labour and the law. London, Stevens.

Kerr, R. (1989) Letter to the editor. The Dominion. December 5: 10.

Kirk (1981) Towards an alternate economic strategy. In Davis, P. (ed) New Zealand labour perspectives: the challenge of the third Depression. Peter Davis.

Levine, S. (1984) Employers associations in Japan. In Windmuller, J. and Gladstone, A.

McAndrew, I. (1989) Bargaining structure and bargaining scope in New Zealand: the climate of employer opinion. New Zealand journal of industrial relations. 14(2): 133148 .

Macarov, D. (1982) Worker productivity: myths and reality. Beverly Hills, Sage.

McDonald, D. (1974) Cooperation and conflict: a trade union point of view. In Howells, J.et al. (ed).

Minister of Labour (1986) Government policy statement on labour relations. Wellington, Government Printer.

Myers, D. (1989) Reforming New Zealand's labour market: back to basics. Speech to the New Zealand Institute of Public Administration. August 3.

Moore, W. and Newman, R. (1985) The effect of right-to-work laws: a review of the literature. Industrial and labor relations review. 38(4): 571-585.

New Zealand Business Roundtable (undated) Critique of the Labour Relations Act.

New Zealand Business Roundtable (1986) New Zealand labour market reform: a submission in response to the Green Paper.

New Zealand Business Roundtable (1987a) Freedom in employment: why New Zealand needs a flexible decentralised labour market. 
New Zealand Business Roundtable (1987b) A submission to the Labour Select Committee: The Labour Relations Bill.

New Zealand Business Roundtable (1988) Labour markets and employment: New Zealand Business Roundtable statements on labour relations.

New Zealand Employers Federation (1987) The Labour Relations Bill. The Employer. April 1987: 1-6.

New Zealand Employers Federation (1988a) Annual report.

New Zealand Employers Federation (1988b) The wage round. The Employer. April 3.

New Zealand Employers Federation (1988c) Submissions of the NZEF to the Royal Commission on social policy: summary. The Employer. February 1.

New Zealand Employers Federation (1989a) Award renewals. The Employer. April 5.

New Zealand Employers Federation (1989b) Unions: friends of their members? The Employer. April 3.

New Zealand Planning Council, Economic Monitoring Group (1986) Labour market flexibility. Wellington.

Pearson, D. and Thorns, D. (1983) Eclipse of equality: social stratification in New Zealand. Sydney, Allen and Unwin.

Rose, D. (1986) Introduction: the pursuit of full employment: macroeconomic perspectives. New Zealand journal of industrial relations. 11(1): 65-82.

Rowe, J. W. (1983) Implications of voluntary unionism: the employer's perspective. In Brosnan, P. (ed).

Ruben, G. (1989) Collective bargaining and labor-management relations, 1988. Monthly labor review. 112(1): 25-39.

Rudman, R. (1974) Employer organisations: their development and role in industrial relations. In Howells, J. et al. (ed).

Schmidt, F. (1972) Industrial action: the role of trade unions and employers' associations. In Aaron, B. and Wedderbum, K. Industrial conflict: a comparative legal survey. London, Longman.

Sisson, K. (1987) The management of collective bargaining: an international comparison. Oxford, Basil Blackwell.

Smith, D. (1978) A critique of worker participation in New Zealand. New Zealand journal of industrial relations. 3(2): 71-79.

Smith, D. and Turkington, D. (1981) A profile of voluntary collective bargaining in New Zealand. Industrial Relations Centre, Victoria University of Wellington.

Smith, I. (1975) Is employment properly analysed in terms of contract? New Zealand universities law review. 6(3): 341-365. 
Trotter, R. (1986a) Reforming the labour market: idle dreams or real prospects? In New Zealand Business Roundtable (1988).

Trotter, R. (1986b) New Zealand labour market reform: class struggle or productivity struggle? In New Zealand Business Roundtable (1988).

Turner, S. (1987) Night shift in a pickle factory. In Ezorsky, G. (ed) Moral rights in the workplace. Albany, State University of New York Press.

Vranken, M. (1986) Comment New Zealand journal of industrial relations. 11(1): 5-7.

Vranken, M. and Hince, K. (1988) The Labour Court and private sector industrial relations. Victoria University of Wellington law review. 18(2): 105-140.

Walsh, P. (1983) Union membership policy in New Zealand: 1894-1982. In Brosnan, P. (ed).

Walsh, P. (1989) Summary. In Harbridge, R. (ed) (1989).

Weber, A. (1967) Stability and change in the structure of collective bargaining. In Ulman, L. (ed) Challenges to collective bargaining. Englewood Cliffs, Prentice-Hall.

Wedderburn, K. (1984) Labour law now - a hold and a nudge. Industrial law journal. 13(2): 73-85.

Wedderburn, K. (1987) Labour law: from here to autonomy? Industrial law journal. 16(1): 1-21.

Weir, J. (1989) Lawyer criticises securities law proposals. The Dominion. November $30: 17$.

Willman, P. (1986) Technological change, collective bargaining, and industrial efficiency. Oxford, Clarendon Press.

Wilson, M. (1979) A few observations on the law relating to security of employment. In Legal Research Foundation The industrial law seminar. Auckland University.

Windmuller, J. and Gladstone, A. (1984) Employer associations and industrial relations: a comparative study. Oxford, Clarendon Press. 